\title{
Making Private Public: Representing Private Devotion in an Early Modern Funeral Sermon
}

\author{
Lars Cyril Nørgaard
}

On 1 October 1639, Christian Friis of Kragerup died. Born in 1581 and initially educated at the royal school in Sorø, he toured Europe together with his brothers and studied at leading universities. On his return in the winter of 1607 , he served at the court of Christian IV (1577-1648). During the Kalmar War (1611-1614), Friis proved himself a skilled tactician and a careful administrator: these achievements during wartime paved the way for rising up the ranks and, in December 1616, he was appointed high chancellor. The passing of this prominent political figure was commemorated, first, at the Church of Our Lady in Copenhagen. This liturgical event took place on 23 October 1639, and the bishop of Zealand, Jesper Rasmussen Brochmand (1585-1652), was charged with the ceremony. As prescribed, the bishop delivered a funeral sermon: this oral event was later edited and published. ${ }^{1}$ Of course, this printed version of the sermon does not mirror the occasion when the sermon was heard as part of a liturgical programme. The print is an edited version of the event: it marks the transition from a public event to a published event. Can we speak, within the space of such a transition, of anything private?

Brochmand's sermon belongs to a larger body of commemorative texts a so-called funeral work. ${ }^{2}$ As the high chancellor of King Christian, Friis was also commemorated at the University of Copenhagen. This took place the day after his funeral, when professor of theology Hans Hansen Resen (1596-1653)

1 Brochmand, Jesper Rasmussen, Hielp aff Himmelen, det er: Den CXXI. Davids Psalme / andragen / der Christian Frijs til Kragerup / Kongel. May. Canceller / Danmarcks Rigis Raad / Befalnings = Mand offver S. Knuds Kloster udi Fyen / oc Munckeliff = Kloster udi Norge / hans Lijgs Begrengelse / med Adelige Ceremonier bleff udi vor Frue Kircke i Kiøbenhaffn huldet / udi hans Kongl. Maj. Egen Ncerverelse / oc Danmarckis Riges Raads / oc fornemme Adels offver = varelse / saa oc Geistliges oc Verdsliges Folckrige Forsamling (Copenhagen, Melchiore Marzan: 1640). The title page refers to the presence in the church room of the king, members of the high council, prominent members of the nobility, and a large crowd of clergymen and citizens.

2 See Moore C.N., Patterned Lives. The Lutheran Funeral Biography in Early Modern Germany (Wiesbaden: 2006) 19ff. For Catholic funeral sermons, see Régent-Susini's contribution to this volume.

(C) LARS CYRIL NøRGAARD, 2022 | DOI:10.1163/9789004153073_018

This is an open access chapter distributed under the terms of the CC BY-NC-ND 4.qlicense 
delivered an oration. ${ }^{3}$ It is unclear when this oration was published. Its prefatory statement is dated 22 November 1639 and was written by Claus Plum (1585-1649), professor of law and dean of the University. Resen's oration is appended with several poems that commemorate the deceased and the event of his commemoration at the University. Indeed, Brochmand authored one of these poems. In addition to these two prints, a compilation of popular songs was published, ${ }^{4}$ and another longer poem related to the chancellor's death can also be identified. ${ }^{5}$ In prefatory statements to his later works, the physician, natural historian and antiquarian Ole Worm (1588-1654) also lauded Friis by evoking his contribution to the scientific exploration of, e.g., rune-stones and inscriptions. ${ }^{6}$ Such different genres - a sermon, an oration, poems, popular songs, and dedications - belong to the symbolic space of commemoration that Friis's death prompted. Indeed, we must include an epitaph in sandstone that towers in the Abbey Church of Sorø and that was completed before 1648. This monument, together with an engraved representation of it, is also part of the commemorative space in which the memory of Friis lives on after his death.

In the following, I shall focus on Brochmand's printed sermon and heed special attention to its depiction of Friis's death. ${ }^{7}$ As mentioned above, the bishop of Zealand delivered his sermon on 23 October 1639, but this sermon also relates events that transpired from 17 September until 1 October 1639, when Brochmand administered the final spiritual care of the chancellor. While not unique, ${ }^{8}$ this level of disclosure requires careful consideration. Strategically, the preacher includes information to which his addressees - the immediate audience in the church and all subsequent readers - would not otherwise have

3 Resen Hans Hansen, Orationis Funebris De Magnifico, Perillustri \& incomparabili Heroe Dn Christiano Frisio (Copenhagen, Salomon Sartor: 1640). The event was announced in a programme published the day before.

4 Barløse Oluf Rasmussen, Sørgelig Klage offver Den Erlige / Velb. oc Strenge Ridder H. Christen Friis til Kragerup / oc Kong: May: Canseler / Danmarckis Rigis Raad / Nu salig $i$ Herren / tile $n$ Christelig Amindelse / oc hans effterlatte højbedrøffvede elskelige Frue / Fru Barbara Wittrop / Sampt deris elskelige / Velbyrd: oc Adelige Børn / til nogen Trøst / offver deris Velb: S. Herris oc Faders hcederlig oc saglig Affgang (Copenhagen, Salomon Sartor: 1639).

5 Meier Johannes, In Funere Christiani Frisii, Domini de Kragerup, Equitis Aurati [...] lachrimce et planctus veri doloris (Copenhagen, Melchior Martzen: 1639).

6 See, e.g., the prefatory statements in Worm Ole, Monumenta Danica libri sex (Copenhagen, Joachim Moltke: 1643); idem, Museum Wormianum seu Historia Rerum Rariorum (Leiden, Jean Elzevir: 1655).

7 I have elsewhere (in Danish) discussed the sermon's position within the overall funeral work, specifically with attention to the epitaph in Sorø, Nørgaard L.C., "Overvejelser over en ligprædiken", Kirkehistoriske Samlinger (2021) 7-39.

8 Moore, Patterned Lives 80. 
been privy. Intimate details about the process of dying, then, become part of the public image of the deceased. These are not hidden under the seal of confession or silenced by other codes of confidentiality. In print, experiences of dying are represented, and the Lutheran funeral sermon brings forth what could not otherwise have been known.

\section{1 \\ Fear as Ideal}

These personal moments pertain to the pietas of the deceased. Of course, such public portraits of private devotion were no neutral descriptions: the image of personal devotion flows naturally from the well of the sermon's epideictic language usage. As one of the three genera of discourse which Aristotle identified, epideixis from epideiknusthai means to give an exhibition or a display. The middle voice also allows for the meaning where individuals show off their rhetorical skill. This genus comprises speeches of both praise and blame, which act as a means to accomplish a specific communicative end. Epideixis prioritises present realities that the speech either praises or blames according to the ideal of to kalon ('the honourable'). While Aristotle limited epideictic speeches to a demonstration of skill, whereby its listeners became spectators to a show of skills, later interpreters like Quintilian saw a broader application of this genus. The orator aims to establish past actions of an individual as signs of virtues or vices, whereby the audience is encouraged to believe that this individual will perform similar actions in the future. However, the domain of praise was not limited to historical individuals: the sophists praised other objects such as animals, while Quintilian stretched the list to include gods, cities, monuments, places, and other inanimate objects. ${ }^{9}$

Brochmand's sermon belongs to the rhetorical genus of epideixis despite this type of speech falling somewhat prey to Protestant suspicions. Thus, the sermon's 'Første Part' ('first part') engages with Friis's 'Liffs oc Lefnets' ('life and deeds'), before turning to his 'saligste Affskeed fra denne Verden' ('most pious departure from this world'). ${ }^{10}$ These personalia unfold in a little less than forty pages, ${ }^{11}$ and they constitute the object of praise, that is, the subject of praise. However, the sermon's encomium is not limited to this personal level.

$9 \quad$ For this speech type and its Greco-Roman roots, see Pernot L., La rhétorique de l'éloge dans le monde gréco-romain (Paris: 1993); idem, Epideictic Rhetoric: Questioning the Stakes of Ancient Praise (Austin, TX: 2015).

$10 \quad$ Brochmand, Hielp aff Himmelen 32.

11 Ibidem, 32-70. 
Initially, the 'Indgang \& Fortale' ('entry and preface') proposes an exegetical elaboration of the fear of God. ${ }^{12}$ This theological concept is divided into four aspects: (1) 'ikke at frygte andre end Gud' ('to fear nobody else than God'), ${ }^{13}$ (2) 'intet at have så kært som Gud' ('to love nothing as much as God'),, (3) 'at elske og fremme sin fjende' ('to love and promote one's enemy'), ${ }^{15}$ and (4) 'at stå fast på Guds bud, selvom hele verden er imod det' ('to insist upon God's command even if the whole world is against it'). ${ }^{16}$ This four-fold interpretation is elaborated by reference to biblical figures, and past actions performed by these figures become signs of the fear of God. Thus, the sacrifice of Isaac (Genesis 22:2-8) is evoked as proof that fear springs from the univocal love of God, while Moses (Exodus 10), King David (Psalm 73), and the Apostle Paul (Romans 8 ) prove that the fear of God does not comply with worldly standards.

Thus, the prefatory statement and its four-fold analysis of fear does not offer formal definitions, but rather evokes past individuals and displays how they enacted virtues. Moreover, these displays are structured around 1 Timothy 4:8: 'Gudfryctighed er nyttelig til alle Ting / oc hafver forjettelse baade paa det nærværende oc det tilkommende Liff' ('the fear of God is useful in every regard, holding promise for both the present life and the life to come'). ${ }^{17}$ On this scriptural basis, Brochmand outlines what it means to fear God before he turns to its reward in this life and in the next life. The biblical verse mirrors what, in its rhetorical essence, is the concern of epideixis: this genus of speech offers praise or blame, but it advocates no specific course of action, because it evaluates actions in the light of an abstract ideal. The fear of God serves as an honourable state that biblical figures have accomplished by their past actions and that pertains to the present and the future of the collective.

Concluding his initial exegesis, Brochmand turns to $P$ s 121:1-8 and remarks how $P s$ 121:1-2 engages with the fear of God as a stance that humans either dismiss or work towards, while $P s 121.3-8$ outlines the many benefits that can be procured by always fearing the divine. ${ }^{18}$ This distribution of the biblical text maps 1 Tim 4:8 and its distinction between the ethical analysis - the substance of the epideictic language usage - and the kinds of actions that support this vision of the common good, i.e. the exhortative end. Now, the sermon opens

\footnotetext{
12 Ibidem, 4-31.

13 Ibidem, $5^{-8 .}$

14 Ibidem, 8-11.

15 Ibidem, $11-15$.

16 Ibidem, $15^{-20}$.

17 Ibidem, 4.

18 Ibidem, 28-3o.
} 
by reproducing these precise verses from $P s$ 121, ${ }^{19}$ and in his account of Friis's death Brochmand also remarks how the chancellor, as he was dying, 'trøstede sig meget med den hundrede en oc tuiffvende Davids Psalme' ('took great comfort in David's 121st Psalm'). ${ }^{20}$ Indeed, Friis would often cite this text by heart, and therefore his widow, Barbara Wittrop (1591-1653), wished that it 'maatte udi hans Lijgs Begiengelse fremsættis oc forhandlis' ('should be presented and explicated at his funeral ceremony'). Accordingly, the sermon's longest exposition, entitled 'Den Anden Part' ('the second part'), analyses $P S{ }_{121 .}{ }^{21}$ Moreover, this part of the sermon explicates hvor udi en sand Gudfryctighed monne bestaa' ('in what a true fear of God should consist') before moving on to 'hvade gode oc gafn dend med sig monne føre' ('what value and benefit this should bring with itself'). ${ }^{22}$ Following the outline of the prefatory statement, Brochmand elaborates the fear of God with reference to $P S$ 121:1-2, ${ }^{23}$ and exhorts listeners and readers about its 'Nytte oc gaffn' ('utility and benefit') with reference to $P s$ 121:3-8. ${ }^{24}$ Thus, the funeral sermon clearly creates an intertextual echo that lingers across the threshold between theological claims to universal truths and the historical account of particular experiences. In more implicit ways, this link is reiterated as biblical passages are recycled. Having been explicated during the process of dying, these passages reappear in the theological sections: the print posits a relationship between specific experiences, as narrated by the preacher, and a conceptual reality, as elaborated by the same. As such, it is a matrix for exemplarity.

\section{$2 \quad$ Death as Dialogue}

The sermon's 'Første Part' ('first part') describes Friis in two sequences: it deals with his life and deeds and then outlines his departure from the world. This two-pronged approach is typical and can be found in almost every Lutheran funeral sermon from the seventeenth century. In Brochmand's sermon, it also resonates with the linking of 1 Tim 4:8 with Ps 121:1-8. The fear of God, like the biographical sketch, combines two temporal orders: one sequence of events unfolds in this life; the other points towards the next life. Past and future are parallel, and thereby the epideictic speech, as an oratory form, addresses the

\footnotetext{
19 Ibidem, 1-3.

20 Ibidem, 62.

21 Ibidem, 71-164.

22 Ibidem, 73.

23 Ibidem, 71-102.

24 Ibidem, 102-164.
} 
present condition of its audience. Relating these temporal orders to each other, Brochmand's description of Friis is asymmetrical, however. The bishop clearly favours what pertains to the process of dying, that is, the information to which he has direct access. Accordingly, the chancellor's life comprises less than one third of the encomium, ${ }^{25}$ although this part, chronologically, covers the period from November 1581 until August 1639. The rest of the description focuses on the process of dying that lasted from 7 September until the early hours of 1 October 1639, that is, less than one month.

Within this month, the period from 7 September until 13 September 1639 constitutes a particular subsection of events. Brochmand relates that Friis fell ill at his apartments in Copenhagen Castle, and, most likely based on the attending doctors' reports, he recounts several diagnoses and the corresponding interventions. ${ }^{26}$ On 13 September, the preacher states, Friis felt 'temmelig Svaghed udi Legemet' ('a substantial weakness of the body') but no longer wanted to neglect 'Siælen' ('the soul'). Therefore, he commissioned the services of the court preacher Jens Pedersen Schjelderup (1604-1665), who offered the body and blood of Christ to the suffering chancellor and his wife. ${ }^{27}$ The distinction between body and soul, introduced in the narrative by Friis, corresponds to, on the one hand, what has been recounted about Friis's life and, on the other hand, what will be narrated about his departure from the world. The medical interventions, targeting the body and trying to combat its finitude, mark the end of earthly existence and transition into another register that focuses on the eternal destiny of the soul and requires theological expertise:

Den 17 Septemb. der jeg hjemkom aff Kirckernis Visitation, oc jeg da denne gode S. Herre besøgte / oc ønskede hannem Trøst aff Himmelen ved Jesum Christum / da svarede den S. Herre: Jeg finder aff Guds gode Aand retgod oc frydefykd Trøst / oc sagde derhos: Statum est apud me mori. Det er sluttet i mit hjerte / at ville døe. ${ }^{28}$

On 17 September as I returned from church visitations, I proceeded to visit the good, blessed Lord and wished him comfort from heaven in Jesus Christ. To this, the blessed Lord answered: from God's good Spirit, I find sufficient and peaceful comfort. Furthermore, he said: statum est apud me mori. In my heart, it has been decided that I want to die.

\footnotetext{
25 Ibidem, $3^{2-44}$.

26 Ibidem, 44-48.

27 Ibidem, 46-47.

28 Ibidem, 48.
} 
Until this point in the biographical account, Brochmand has utilised a third-person perspective that, omnisciently, narrates the past. The last part, however, introduces the first-person singular. Thus, the bishop becomes a character in the biographical story that he recounts as the listener-reader is made privy to a series of meetings between Brochmand and Friis. These are dated 17 September $1639,{ }^{29} 18$ September $1639,{ }^{30} 24$ September $1639,{ }^{31} 27$ September $1639,{ }^{32} 29$ September $1639,{ }^{33}$ and 1 October $1639 \cdot{ }^{34}$ Reference is also made to the night of 29 September and 30 September, when Friis was quiet and lay motionless in bed. We learn nothing about the days from 18 September until 24 September or about 25 September, 26 September, or 28 September. These meetings fixate the description to Brochmand's physical presence: we see and hear what he saw and heard. The previous description of Friis and his life is accomplished in the third person and thereby distances itself from the object of praise, immobilising Friis in his biographical itinerary and making him into a perfect image for the audience's imitation. This constitutes the construction of a stable ethical model. The apostrophe to the dying individual turns our attention to the individuality of the deceased. ${ }^{35}$

At their first meeting, the bishop refers the chancellor to the Lord's Prayer and, specifically, to $M t$ 6:10: 'Skee din Villie paa Jorden som i Himmelen' ('Your will be done on earth as in heaven'). Hereafter, the bishop 'holt hannem Jesu Christi Eksempel for' ('related him the example of Jesus Christ'), and, more specifically, showed in words how Jesus had prayed in Gethsemane (Mt 26:36-46). ${ }^{36}$ In response, Friis states that he, at this moment and by the grace of his Saviour, is ready 'at dricke Dødens Kalck' ('to drink from the chalice of death'), but he is unsure if he 'en anden Tiid kand være saa bequeem dertil' ('would feel so at ease at another time'). The dying individual is comforted by reference to Acts 1.7, which Brochmand interprets in the following manner: 'Dødens Tijd staar i Guds Haand / oc er skiult for vore Øjne: hvorfor at saadant

29 Ibidem, 48-49.

3 Ibidem, $49^{-56}$.

31 Ibidem, $5^{6-63}$.

32 Ibidem, 63-64.

33 Ibidem, 64-65.

34 Ibidem, $65^{-67}$.

35 The anchoring of the perspective to Brochmand's mind is not absolute. About the interval between 24 September and 27 September, the sermon remarks that Friis repeated many pieces of Scripture, found joy in the heavenly glory about to be bestowed upon him, prayed the Lord's Prayer, recited the Articles of Faith, read $L k$ 2:29-30 and Ps 121, cf. Brochmand, Hielp aff Himmelen 61-63. These pieces of information are not anchored to the 'I', but rather stated from the Olympic position of the third-person narrator.

Ibidem, 48. 
skal indstillis udi Guds egen Villie / hvilcken I med all lydig Hørsomhed skal underlegge eders Villie' ('the moment of death lies in the hand of God and is hidden to our eyes: accordingly, this moment should be relegated to the will of God to which you, in careful obedience, should submit your own will'). ${ }^{37}$ To this interpretation, the dying chancellor responds: 'Skee da udi Jesu Naffn Guds Villie / enten det behager Gud / det skal være til Lifvet eller til Døden' ('in the name of Jesus, let, then, the will of God be done, whether it pleases God that this entails life or death'). ${ }^{38}$ This acquiescence ends the first exchange: Brochmand does not mention the presence of other individuals, and, while the two men might not have been alone, the exchange is presented as such.

The sermon, as performance and publication, grants access to something that the addressees would not have had access to. Indeed, we learn about Friis's unease not with death itself but with the process of dying. On 17 September, the chancellor is ready to die but worries that he, as the process of dying continues, will lose his conviction. Such emotional states can also be found in medieval and early modern texts that formulate advice on the good way to die. Indeed, this genre often presents advice as a conversation during which a figure of authority educates someone in need of guidance. In line with this dialogical structure, a second meeting, dated 18 September, unfolds as Friis's condition worsens and he exclaims to the bishop:

Udi Jesu Blods kraft vil jeg stride / oc jeg er vis paa / at den Guds om gaff mig Jesum / hand skal icke undfalde mig / indtil all Strijden vel er offverstanden, Oc der hos sagde hand: O hvad er jeg meget svag: Gud stat mig udi min Svaghed bij. ${ }^{39}$

By the power of the blood of Christ I shall fight, ${ }^{40}$ and I am certain that the God, who gave me Jesus, he will not let me down until all fighting is over. In addition, he said to me: Oh! how very weak I am: God protect me in my weakness!

Like in the first dialogue, the bishop addresses a worry that is particular but not specific to Friis. Brochmand's response voices $L k 15: 3^{-7}$ and the Parable of the Lost Sheep. He identifies Friis as a 'skrøbelige Faar' ('a weak sheep') that Jesus

37 Ibidem, 49 .

38 Ibidem, 49 .

39 Ibidem, 5 o.

40 This refers to the words uttered by Brochmand as he comes to the deathbed: they originate from 1 Tim 6:11-16 (and not from 1 Tim 6:7-8 as the print notes in the margin), cf. Brochmand, Hielp aff Himmelen 49-50. 
lays on his shoulders, promising not to let go of him until he has carried him through death's darkness, through its 'besværlige Dal' ('troublesome valley'), and into the realm of eternal honour. These words transition, exegetically, into a reading of $P S$ 23, and Friis 'faldt [...] straks ind i Ordene / oc self klarligen dend gandske Psalme fra Begyndelsen oc til enden opregnede' ('immediately joined the recited words and, by himself and in clear voice, recounted the entire Psalm from the beginning until the end'). ${ }^{41}$ Here, the sermon ascribes a level of agency to the dying individual. Indeed, Friis would allegedly repeat a specific verse (Ps 23:4) and state the following as his uptake:

Jeg finder i mit Hierte / at min Jesus er mit Lius / oc hand vil liuse for mig ind i Himmerige / oc jeg tviler icke / at hand jo vil selff tage mig ved Haanden / oc lede mig igennem Dødens mørcke Dal ind i Himmeriges. ${ }^{42}$

In my heart, I find that Jesus is my light, and he will shine a light for me into heaven, and I have no doubt that he, indeed, shall take me by the hand and guide me through the dark valley of death and into the heavenly realms.

Now, the print does not relate the implied biblical framework, but Friis's words echo Jn 8:12: 'I am the light of the world. Whoever follows me will never walk in darkness but will have the light of life'. Indeed, Brochmand proceeds by interpreting $J n$ 14:6 and $J n$ 5:24. Thus, the dying chancellor is taking active part in the interpretation of his death, and Friis, increasingly, speaks the language of Scripture. As such, the funeral sermon imitates the itinerary of, e.g., catechetical manuals. Its dialogical exchange, however, relates affective states, and Brochmand therefore recounts affects as he witnessed them at the deathbed:he is an eyewitness to different emotional states and the ways in which they become manifest. About this eyewitness, that is, the bishop himself, we learn nothing: he paints a portrait of the dying Friis, but his own emotions are not narrated. In this connection, Brochmand describes what was seen and the context within which he beheld the chancellor. He does not reproduce, it seems, the ways in which he, as a viewer, was affected by viewing Friis.

41 Ibidem, $50-51$.

42 Ibidem, 51. 


\section{$3 \quad$ Intimacy}

The second dialogue, dated 18 September, comes to its conclusion as Friis states: 'Loffvet være Gud for saadan Trøst fra nu oc til ævig Tijd' ('from now until eternity, praise be to God for this comfort'). ${ }^{43}$ After this statement, Brochmand remarks that he next noticed how Friis's hands and arms were cold as ice, while his body was soaked in cold sweat. The observation, presupposing a physical proximity between the two men, makes the bishop ask the chancellor 'om hand icke udi Tijde vilde i Jesu Naffn beskicke sit Huus' ('if he, in time, wanted to set his house in order'). ${ }^{44}$ On the following pages, Brochmand recounts Friis's farewell speeches to his wife and to his children. ${ }^{45}$ These speeches differ, however. The speech to his wife is introduced by the following show of affection: 'der den gode V. Frue med højbedrøffved Hierte kom til Sengen til hannem / racte hande hende Haanden / oc faffnede hende om Halsen' ('when the good, blessed wife with most saddened heart came to him at the bed, he offered her the hand and embraced her around the neck'). ${ }^{46}$ As Friis proceeds to praise his wife, an epideictic speech is recounted inside another epideictic speech. This speech concludes with Friis's wish that 'at hvis hand hafde nogen tjd fortørnet hende / hun hannem det da for Christi skyld vilde tilgiffve' ('if he had ever angered her [the now widow], she would forgive him for the sake of Christ'). The bishop portrays the chancellor's words as having a profound effect upon his wife: she is left speechless by grief. Friis turns next to his children, who are all present, and he delivers an exhortation. He concludes his deliberative speech by enticing the children: 'det er eders Faders sidste Ord til eder / seer til I glemmer dennem aldrig' ('this is your father's last word to you / see to that you never forget it'). ${ }^{47}$ The print, in this regard, extends the limits of human memory, allowing the children to honour their father's wish and not forget his admonition. As a conclusion, the children kneel by their father's bed and receive his blessing.

Six days later, on 24 September, the bishop visits Friis again, and the chancellor asks him to relate something from Romans. Brochmand recites Rom 8:33-34,

\footnotetext{
43 Ibidem, $5^{2}$.

44 Ibidem.

45 Ibidem, $5^{2-54}$. The trope of putting one's house in order is found in medieval and early modern manuals on the good death. For this practice, see, e.g., Palladius Niels, Huorlunde ith Christet Menniske skal paa sin Soteseng beskicke sig til Døden (Copenhagen, n.p.: 1558) Part 4, [Unpag.] 7v-8.

46 Brochmand, Hielp aff Himmelen 53.

47 Ibidem, 54.
} 
and Friis proceeds to quote Rom 8:35 from memory. ${ }^{48}$ Hereafter, the biblical exploration continues, but the bishop just mentions that he evoked 1 John 1:7: 'Jesu Christi / Guds Søns Blod / renser os aff alle vore Synder' ('the blood of Jesus Christ, the son of God, washes us clean of all our sins').${ }^{49}$ Explicating this verse, Friis is told that 'Nu toer Jesus eder med sit Blod aff alt det I nogen Tjd haffver giort Gud imod / saa eders Gud / for eders Jesu skyld / vil aldrig mere ihukmme eders Synder' ('with his blood, Jesus will now clean you of everything you have ever committed against God, so that God, for the sake of your Jesus, never will recall your sins'). ${ }^{50}$ This affirmation of Solus Christus (Christ alone) is part of the dialogue on death, but the dying chancellor reframes its meaning: 'nu beder jeg for Jesu skyld / at det hellige Jesu Legem oc Blod maa mig igjen paa ny meddeelis' ('for the sake of Jesus, I now pray that the holy body and blood of Jesus could be offered to me again') ${ }^{51}$ Indeed, Friis asks if his wife and children might participate in this final communion. Granting him this wish, the final farewells include a listing of the individuals, who, we must infer, were present at Copenhagen Castle. Indeed, these members of the family would also have been seated in the church room.

Describing the family's presence at the deathbed, the bishop writes that Friis, after the communion had been completed, called him to his bed and whispered concerns: his weak body had not allowed him to kneel when receiving the body and the blood of Christ. Brochmand answers this concern by returning to Gethsemane, where Christ knelt and even prostrated out of humility to the divine. However, at the moment of his death, when he was nailed to the cross, he could no longer kneel. Delivering his soul unto God, limitations upon his movement had been imposed and these denied him a physical display of humility. Instead, Brochmand avers, Christ knelt down in his heart. Friis is bound to the deathbed that, by comparison, becomes equal to the cross: he too should kneel in his inner self. ${ }^{52}$ In spatial terms, this advice also creates an intimate zone within a somewhat crowded location: Brochmand's words address a concern that is not voiced openly, but communicated within an intimate space. Words whispered seem to us private. They express doubts that Friis, intentionally, reserved for Brochmand. In his turn, the bishop, from the pulpit and in print, discloses what he had witnessed. The theological response

\footnotetext{
48 Ibidem, 57.

49 Ibidem.

$5^{\circ} \quad$ Ibidem, cf. Rev 7.14.

$5^{1} \quad$ Brochmand, Hielp aff Himmelen 58.

52 Cf. Brochmand, Hielp aff Himmelen 6o-61.
} 
that facilitates the silencing of the reported doubts, then, becomes part of the official portrait of the chancellor, his pious character, and his way of dying.

\section{$4 \quad$ Locating the Soul}

Above, we mentioned how the process of dying is initiated when Friis acknowledges the irreversibility of his condition and, by implication, turns our attention towards the soul. Protestants had rejected Purgatory as a concept: souls, for them, could not go there after death. Where, then, to locate the soul? This question did not have an obvious answer.

Brochmand's sermon first approaches this question in an undated dialogue, probably taking place between 18 September and 24 September. During this period, we learn that Friis would often say: 'Kom Herre Jesu / kom snart: jeg lengis meget effter dig' ('come Lord Jesus, come soon: I very much long for you'). ${ }^{53}$ In addressing this longing, the bishop evokes the martyrdom and vision of Stephen, stating that 'Tijden var icke langt borte / at hand skulde sige: See, jeg seer himmelen aaben / oc Jesum staa hos Guds højre haand' ('the time is not far away, when he should say: Look, I see the heavens opened and Jesus standing at the right hand of God'). ${ }^{4}$ To this, Friis promptly answered: 'Effter den Tjme længis jeg: der paa vil jeg sige, sagde hand: Herre Jesu udi din Haand befaler jeg min Aand' ('for this hour I long: then, I shall say, he said, Lord Jesus, in your hand I give over my spirit'). ${ }^{55}$ By the latter statement, the dying chancellor, silently, makes Stephen's last words into his own: his experience is guided by the martyr's model. Moreover, these words were also used as proof in the prefatory statement. The fear of God entails the love of one's enemy, and Stephen proves this as he, according to Acts 7:6o, asked God that he would refrain from punishing the individuals who were in the process of stoning him. ${ }^{56}$ By way of this model, Friis also anticipates his death. Using biblical

\footnotetext{
53 Ibidem, 56. In the margin, the print relates these words to Revelations 20:22.

54 Ibidem, cf. Acts 7:56.

55 Ibidem, cf. Acts 7:59. This verse was commonly used in Reformation manuals on the preparation for death, see Resch C., "Reforming Late Medieval Ars Moriendi: Changes and Compromises in Early Reformation Manuals for Use at the Deathbed", in Rasmussen T. Øygaarden Flæten J. (eds.), Preparing for Death, Remembering the Dead (Göttingen: 2015) 153-172, here 166.

$5^{6}$ Brochmand, Hielp aff Himmelen 13-14.
} 
language, the chancellor, proleptically, engages with the dramatic moment of death. ${ }^{57}$

As Brochmand recounts another meeting on 27 September, we learn that he had been called for but almost missed the call: he reacted to the second call, however, and upon the bishop's belated arrival at Copenhagen Castle Friis tells him:

Jeg kand icke andet end lade eder vide / at Herren haffver bevist stor Miskundhed mod mig. Nu haffver jeg hvercken ont i Hoffvet eller Hierte / eller i Lemmer; Jeg var en sted henne / hvor alting var saa meget dejligt: Jeg kand icke nocksom sige hvor herlige der var: Men jeg var der saa meget stacket: $\mathrm{O}$ maatte jeg snart komme did igien! ${ }^{58}$

I cannot inform you of anything more than that the Lord has shown me great mercy. Now, I have pains in neither head nor heart nor limbs. I was in some place where everything was so very lovely. I cannot fittingly express how glorious it was there, but just for a brief moment I was there: Oh! May I soon return there!

This statement completes a shift in perception, which was prepared on the preceding pages that evoke Stephen's vision. Until this shift, Friis and Brochmand had exchanged words, and the sermon presents the dying man as increasingly apt in biblical language usage. This aptitude corresponds to his increasing detachment from his body. However, the meeting on 27 September turns from words to a mystical experience. According to Brochmand's immediate response, Christ will soon return the chancellor to this place. Indeed, Friis need not worry about his inability to understand what he had seen. With reference to Paul's vision in 2 Cor 2:9 and 2 Cor 12:2-3, the bishop affirms that such experiences cannot be represented in language. As the individual approaches the threshold between life and death, his soul speaks, and the meaning of its words resides beyond what human language can express. Indeed, Friis is alone with his vision, and should we, then, view such a vision as private? Theologically, the question of salvation, of locating the soul in the everlasting realm, cannot be confirmed by reference to deeds or events. It resides beyond what the public

57 Such continual meditation, whereby the singular moment of death is extended and encompasses all of life, is a feature of the ars moriendi as it developed during the fourteenth and fifteenth centuries, see Hamm B., Religiosität im späten Mittelalter. Spannungspole, Neuaufbrüche, Normierungen (Tübingen: 2011) 475-476.

Brochmand, Hielp aff Himmelen 63. 
might see. Even the bishop by the deathbed cannot confirm this with certainty, and the Lutheran funeral sermons rehearse a level of essential unknowability. Nevertheless, this experience is posited in the description of Friis - it is uttered by the dying chancellor - even though it cannot be narrated fully. The presence of God in an intimate encounter resists representation even as it is represented.

We should remark the quasi-fictional introduction to this meeting, where Brochmand almost misses the call: this circumstance - true or false - underlines the liminal nature of what we learn about Friis. As a framing device, it underlines the ephemeral nature of experiencing the divine. Two days later, on 29 September, Friis evokes the related topic of the angels that will soon 'bære hans Siæl ind i Himmerige i Abrahams Skiød' ('carry his soul into heaven and to Abraham's bosom').$^{59}$ Brochmand proceeds by reading 'den gledelig Loffsang: O Gud vi lofve dig / vi bekiende dig en Herre' ('the joyous song of praise: O God, we praise you / and confess you the only Lord'). ${ }^{60}$ Hereafter, the bishop recalls:

Oc der same Loffsang aff mig vaar udlæst: begyndte hand self allene strax at siunge med livdelig / dog svag / Røst: In te Domine speravi, non confundar in ceternum: Jeg haaber paa dig Herre / jeg skal icke beskæmmis Evindeligen. Oc disse Ord: Non confundar in ceternum: Jeg skal ick beskæmmis Evindeligen: tog hand to eller tre gange igjen. ${ }^{61}$

And when this very song of praise had been read aloud by me, he began immediately by himself to sing with a lively but weak voice: In te Domine speravi, non confundar in ceternum: I have hope in You, Lord, I shall never in eternity be confounded. And these words Non confundar in ceternum: I shall never in eternity be confounded, he repeated two or three times more.

59 Ibidem, cf. $L k$ 16:22. The metaphor expressed the location of the soul before the idea of Purgatory became normative, see Baschet J., Le sein du père: Abraham et la paternité dans l'occident médiéval (Paris: 200o). For the new location of the dead, see Wangsgaard Jürgensen M., "Spacing Death - Facing Death: Conceptualizing the Encounter with Death during the Early Modern Period", in Rasmussen - Øygaarden Flæten (eds.), Preparing for Death, Remembering the Dead 123-151.

6o Brochmand, Hielp aff Himmelen 64.

61 Ibidem, 64-65. 
Initially, it seems Brochmand read from the Danish rendering of Te Deum Laudamus, ${ }^{62}$ before Friis, spontaneously, reverts to the Latin original. ${ }^{63}$ From his use of Latin we could infer that Friis, effectively, is turning back the hands of time: this language use refers back to his youth, his education, and travels in Europe. ${ }^{64}$ Indeed, the chancellor continues by singing Martin Luther's 'Mit Fried und Freud ich fahr dahin' in Danish translation: 'Met glæde oc fryd faer jeg nu hen' (In happiness and joy, I now move on). ${ }^{65}$ Indeed, Friis 'den alleene til Enden klarligen oc redeligen / dog svageligen / udsang' ('sung it by himself to the end in a clear and distinct yet weakly manner'). ${ }^{66}$ When the physical powers left Friis and he could no longer sing, Brochmand continued by reading aloud 'Naar min Tijd oc Stund er forhaand' ('When my time and day has come'). ${ }^{67}$ Friis listens to these words crying and with his hands folded, the tears serving as a material manifestation of words resonating in the interior realm. Without evidence to corroborate the claim, we cannot know if these hymns were sung in the Church of Our Lady. It would have been an obvious choice, however.

The transition from spoken to sung words underscores that the process of dying has entered a crucial stage. Like the mystical vision of heaven that within the biographical outline resists narration, the singing on earth, by the deathbed, is a prefiguration of the angelic song in heaven: it parallels the mundus visibilis with the mundus intellectualis. The parallelism becomes evident after Friis has passed away, and Brochmand concludes his narration:

Siælen staar nu udi største Ære for Guds oc Jesu Ansict / oc uden affladelse tiener oc tacker baade Dag oc Nat Gud / oc haffver erlanget Sejervinding

62 See Thomissøn Hans, Den danske Psalmebog met mange christelige psalmer (Copenhagen, Lorenz Benedict: 1559) 304-308.

63 The Te Deum Laudamus is traditionally ascribed to Ambrose or Augustine. Friis sings the final verse that, in Thomissøn's rendering, sounds as follows: 'Til dig Herre staar all vort haab / derfor lad os icke bliffve til skendzel evindelig' ('In you, Lord, all our hope is placed / therefore let us not ever be to disgrace'), Thomissøn, Den danske Psalmebog $307 \mathrm{v}$.

64 See Lund T.-T., Dagligt liv $i$ Norden i det sekstende århundrede, vol. 14 (Copenhagen: 1901) 48-49.

65 Brochmand, Hielp aff Himmelen 65, cf. Thomissøn, Den danske Psalmebog 333v-334. In Thomissøn, this belongs to the section 'Om Døden / oc begraffvelse' (On death and funeral). Luther's original was based upon the 'Nunc dimittis' or the canticle of Simeon (cf. $L k$ 2:29-32) and was first published in 1524 .

66 Brochmand, Hielp aff Himmelen 65.

67 Thomissøn, Den danske Psalmebog 336v-337v. In Thomissøn, this psalm also belongs to the section on death and funeral. It was originally written by the Lutheran cantor Nikolaus Herman (ca. 1500-1561). 
offver Verden / Synden / Døden / Dieffvelsen / oc siunger denne ny Sang: Loff oc Ære / oc Viissdom, oc Tack oc Prijs / oc Krafft / oc Styrcke / være vor Gud / fra Evighed oc til Evighed / Amen. Legemet som seeis her for Øjen / skal den Herre Jesus udi sin Tijd opvæcke aff Jordens Støff / oc det giøre sit ærefulde Legemligt / effter den Kraft / som hand oc kand giøre sig self alle Ting underdanige. ${ }^{68}$

Now, the soul stands in the greatest honour before the face of God and Jesus and it, incessantly, serves and praises God day and night, and having procured the victory over the world, sin, death, the devil, and now singing a new song: blessing and glory and wisdom and thanksgiving and honour and power and might be to our God, forever and ever! Amen. In due time, the body that now can be seen before our eyes the Lord Jesus shall resurrect from the dust of the earth and make into his honourable body, according to the power with which he can also subject everything to himself.

\section{The Moment of Death}

Before this transition was completed, Friis had been quiet and motionless for hours. In a troubled voice, he repeated 'Herre Jesu / Herre Jesu' ('Lord Jesus, Lord Jesus'), and Brochmand mentions that 'vi [...] alle haffde gjort voris Bøn til Gud for hannem' ('all of us had said our prayers for him to God'). ${ }^{69}$ 'Vi' ('we') implies that the bishop was not alone with the dying man. The pronoun, however, remains unspecified, and it serves, strategically, to underline the following statement:

jeg kom til Sengen til hannem oc sagde: Herre Jesu / lad nu dine hellige Engle lejre sig om denne din udvalde Tienere / oc føre hans Siel ind i Himmerigis ære / der at skue sin Gud oc sin Frelsere Jesum Evindeligen: Aabne hans Siæls Øjne / at hand maa see din Ære: Herre Jesu annamme din Tieneris Aand udi din haand. ${ }^{70}$

I came to him by the bed and said: Lord Jesus, let now your holy angels group around this your selected servant and guide his soul into the glory

68 Brochmand, Hielp aff Himmelen 67-68, cf. Rev 7:12.

69 Ibidem, 66.

70 Ibidem. 
of heaven, in order there to see his God and his Savior, the eternal. Open the eye of his soul that he may see your glory: Lord Jesus, receive your servant's spirit in your hand.

In response, Friis lifts both his arms and, in a quiet voice, says: 'Jesu' ('Jesus', vocative). It seems as if the chancellor is about to pronounce a longer sentence, but, immediately, his breath turns still and, Brochmand explains, 'hvorfor jeg bøjede mig ned til hannem / oc da haffve den Herre Jesus i samme Øjeblick annammet til ævig Ære hans Siæl' ('therefore I leaned down towards him, when the Lord Jesus in the same moment had taken his soul to eternal glory'). ${ }^{71}$ The bishop, withdrawing from this close proximity, proceeds to the blessing of his body that it, in time and together with the soul, would be accepted into the eternal joy of heaven. Then, 'soff [...] denne S. Herre saa sødelig oc sactelig bort udi Jesu Paakaldelse / uden all Legemens besværlig Bevegelse' ('the blessed Lord, sweetly and quietly, died by the calling of Jesus'). ${ }^{72}$ How are we to evaluate this last scene? Is it private or public? It seems that Brochmand's sermon presents the moment of death as an intimate experience. A similar strategy can be identified during the other meetings. The way of dying was part of public praise, but it contains pockets of privacy.

We should recall that the description of Friis's death is part of the overall eulogy of his person. As such, the private scenes and states are part of the epideictic speech, defined by Philipp Melanchthon (1497-1560) as a speech that 'continet laudationem et vituperationem, sed multum interest, utrum personae tractentur, an facta, aut res' ('covers praise and blame but it makes a great difference whether persons or deeds and things are dealt with'). ${ }^{73}$ This classical definition is followed by the equally traditional observation that the praise of an individual requires the relevant commonplaces, known in Greek as topoi and in Latin as loci. Again, this observation is not novel: all rhetorical inventio is structured according to complex commonplaces because the orator, without being an expert in all domains, must be able to speak about all topics. The topoi/loci facilitate a method that allows a trained orator to

\footnotetext{
71 Brochmand, Hielp aff Himmelen 67.

72 Ibidem, 67.

73 Melanchthon Philipp, Opera Omnia, vol. 2/2, eds. W.P. Weaver - S.Strohm - V. Wels (Berlin - Boston: 2017) 314.
} 
find relevant ideas for every situation. Since antiquity, lists of relevant commonplaces were compiled. They aim to be exhaustive, but, as the epideictic speech gained in popularity, such lists multiplied. With regard to the praise of persons, lists survive from the fourth century BC. Thus, Isocrates outlines eight commonplaces, ${ }^{74}$ while Menander Rhetor II posits a longer list. ${ }^{75}$ In Melanchthon, we find several lists including the following: 'Patria, Sexus, Natales, Ingenium, Educatio, Disciplina, Doctrina, Res gestae, premia rerum gestarum, unitae exitus, opinio post mortem' ('homeland, ancestry, birth, character, education, career, habit, knowledge, honours won by actions, death, and name after life'). ${ }^{76}$ Laurent Pernot remarks that such lists follow a division of goods. Homeland, ancestry, birth, and character refer to exterior goods that the person enjoys throughout life, while education, deeds, and honours are goods of the soul, which generate certain actions and virtues. ${ }^{77}$ The rise of epideixis hinges upon the multiplication of social scenarios during the Imperial period, which required such a speech. However, the first rhetorical eulogies were public funerals. Within this setting, rhetorical praise adhered to a chronological order of events: death facilitated the telling of the history of society in which the deceased individual had played a role. Accordingly, encomium seems to rule out privacy, understood as something that is not public: praise and blame target the good of the object, that is, the virtuous actions of an individual, and such goods are inherently social; visible actions manifesting virtues that can be praised. Here, privatus takes on an entirely negative meaning, and such an understanding is still preserved in Melanchthonian rhetoric:

In funebribus privatorum persona laudatur iis, quos praescripsi, locis: natalibus, educatione, cursu gestisque vitae. In funebribus multorum laus aliunde petitur, ut a decoris patriae, gentis, urbis, pro qua illi mortem oppetierunt. Deinde a commodis, quae peperit illorum mors, quin et a generali mortis ratione, qua fere in consolando, si desit honestior occasio, utimur. ${ }^{78}$

74 See Pernot, Epideictic Rhetoric $35^{-36 .}$

75 Ibidem, 32-34.

76 Melanchthon, Elementorum rhetoricae 314. This list is close to the outline in Cicero Marcus Tullius, De Inventione 1.34-36 (Cambridge, MA: 1949) 70-74. Another list appears in Melanchthon's earlier De Rhetorica, where six loci are posited: 'Natales' ('birth'), 'Educatio' ('upbringing'), 'Adolescentia' ('youth'), 'Iuventus' ('manhood'), 'Senectus' ('old age'), and 'Mors' ('death'), Melanchthon Philipp, 'De Rhetorica libri tres', in Opera Omnia, vol. 2/2, 87. This shorter list of loci is no less complex, since its entries are not boxes to be checked off but vantage points that the orator can use to structure his praise of an individual.

77 See Pernot, Epideictic Rhetoric 37-39.

78 Melanchthon, De Rhetorica 92. 
In the funerals of private individuals, the persona is praised by these prescribed topics: birth, upbringing, life trajectory, and deeds. In the funeral of many other individuals, praise can be sought in other sources, like from the glory of the country, people [and] city on whose account they went to their deaths. Thereafter, [praise can be sought] from the advantages that their death had produced: indeed, and if there is not a better alternative, [praise can be sought] from the general destiny of death as a way that we usually use in consolation.

The public funeral of a private individual places great constraint upon epideictic speech because its object of praise - the deceased individual - is not in itself praiseworthy. Put differently, individuals are private in death when their death has no immediate meaning to society and when their life has left no clear mark on the history of the collective. Indeed, the term privatus can refer to an individual that has no civic office. ${ }^{79}$

In Brochmand's rendering of Friis's life that precedes his illness and death, he utilises many of the abovementioned loci, and the print evokes them in the margin. In total, nineteen marginal notes refer to various aspects of the chancellor's life. Initially, the sermon recounts the birth of the deceased, ${ }^{80}$ his noble heritage, ${ }^{81}$ Christian upbringing in his parents' household and further education at the royal school of Sorø. The latter locus about education refers to the parents' actions: they did not neglect to have Friis baptised or 'at holde hannem til Bogen / oc ellers udi god Optuctelse' ('to educate him and also to give him a proper upbringing'). ${ }^{82}$ Furthermore, they also had him enrolled into 'den berømte Kongelig Skole' ('the famous royal school'). Together, this early part of the life of the deceased corresponds to headlines in the margin: these could comprise the loci of homeland, ancestry, birth, and education, whereby they praise exterior goods.

However, the locus on education introduces an element that is not about goods awarded to Friis, but rather a result of his own enterprise: we are informed that the chancellor showed intellectual promise and progress at Sorø, which constitutes a good of the soul. This perspective is continued in the account of his travels, ${ }^{83}$ which prefaces his way of life and deals with the career embraced by Friis at the court of King Christian IV. ${ }^{84}$ These two

79 On this root meaning of riv $^{*}$, see Bruun's contribution to this volume.

8o Brochmand, Hielp aff Himmelen 33.

81 Ibidem, 33-34.

82 Ibidem, 34-35.

83 Ibidem, $35^{-37}$.

84 Ibidem, 37. 
sections align, making Friis's youth in foreign lands a preparation for his royal service. Hereafter, his career trajectory is charted: Brochmand mentions Friis's role as an envoy to Holland, ${ }^{85}$ together with his critical function during the Kalmar War. ${ }^{86}$ We also learn how he travelled with Christian IV to England, where the King visited his older sister, Anne of Denmark (1574-1619), and her husband, King James I (1566-1625). ${ }^{87}$ Brochmand mentions that Friis, after his safe return to Denmark, was appointed 'Prinselig Højheds Hoffmester' ('High-Master of the Princely Court'), ${ }^{88}$ before he was knighted and became member of the Royal Chancellery. That same year, in December 1616, Friis was appointed High Chancellor. ${ }^{89}$ The sermon mentions Friis's belongings, ${ }^{90}$ while his marriage to Barbara Wittrup also plays an important role. ${ }^{91}$ At the end of the sermon, their children are mentioned by name. ${ }^{92}$ The latter section corresponds to the initial rendering of Friis's birth and heritage: the portrait of his individuality is framed by his family name. The framing underlines how the pure portrait of an individual is a challenge to epideixis that, in its traditional model, subsumes individuality under a shared social identity: the particularities of Friis's life illustrate a shared model of identity. However, the final locus in the description returns to individuality. Entitled 'Christelig førte Leffnet' ('Christian conduct'), the section states:

Ald sin Lifvis tijd haffde den gode S. Herre / Gud hierteligen for Øjne / paakallede hannem inderligen i alle sine Idretter forsømmede aldrig frivilligen Guds Tieniste / forvarede sig / det allermeste it Menniske mueligt være kunde / fra det hans Samvittighed kunde besverge: vilde hver mand vel / ingen ilde med Forset [...] Oc med faa Ord sagt / holdte sig i alt sit Leffnit / som en retsindig Christen eigner oc sømmer. ${ }^{93}$

For all of his life, the good and blessed Lord held God before his eyes with joy, evoking him internally in all his deeds and he never willingly neglected the worship of God: as much as it is humanly possible, he kept himself from what might trouble his conscience; and he wanted the best

\footnotetext{
85 Ibidem, $37-38$.

86 Ibidem, $38-39$.

87 Ibidem, 40-41.

88 Ibidem, 41.

89 Ibidem, 41.

$90 \quad$ Ibidem, 39; 40; 41-42.

91 Ibidem, 39-40.

92 Ibidem, 43-44.

93 Ibidem, 44.
} 
for all men and intended no evil for anybody [...] To put it in so many words, he carried himself in everything in his life as is fitting and appropriate for a just Christian.

This statement is slightly surprising, since we have heard little about the chancellor's religious beliefs. It seems rather to prepare what Brochmand is about to explicate, namely Friis's death and its theological value. Until this point, the sermon has portrayed the public image of the deceased, and Brochmand therefore remarks:

Foruden mange andre den Salige Herris berømmelige Idretter / som her icke giøris behoff vidløftiger at udføre / efftersom størsteparten enhver vitterlige ere / oc hans Kongelige Mayts: egen Kongelige oc Naadiste ofverværelse til denne hans Jordefærd..$^{94}$

In addition, [there are] many other [and] well-known actions of the blessed Lord, which here do not need to be lauded, since most are known to everyone, and since His Royal Majesty is present in His royal and merciful person to witness this his funeral ceremony.

Hereafter, the sermon proceeds to detail Friis's death, and this description, it seems, is not redundant but rather worthy of attention. Thus, Brochmand's recounting of Friis's 'Liffs oc Lefnets' ('life and deeds') is publicly known, while his 'saligste Affskeed fra denne Verden' ('pious departure from this world') involves scenes that reside beyond what the public knows. Indeed, this part of the representation posits a level of essential unknowability, which even extends to Brochmand and to dying Friis.

94 Brochmand, Hielp aff Himmelen 42. The presence of Christian IV is also communicated on the title page. Brochmand supplies further reasons why he condenses Friis's life. According to the bishop, the deceased 'alvorligen begierede / at alt for meget Verdslig Prang / saa vel udi hans Ligs Begiengelse udi sig selff / som udi Ord oc Tale offver hannem / at matte forbigaais' ('firmly desired that too much worldly glory should be disregarded in the funeral ceremony itself as well as in the words and speech about him'), ibidem, $3^{2-33}$. Thus, the abbreviated Vita expresses a devotional stance of humility. Such second-hand professions of humility are common within the Lutheran funeral sermon and constitute a preemptive response to the suspicions against hyperbolic praise. 
Brochmand's funeral sermon transitions from a public event - an oration delivered to an audience - to a published event - the printed page making information available to readers. This transition rehearses a social model of identity that is essentially public: it outlines the life of the deceased in keeping with a list of loci, which allows the speaker to praise past actions as manifestations of virtues and thereby as societal goods. Based on this model, the sermon introduces information that is not in the public domain: Brochmand shows Friis where nobody could have seen him and confirms the public image of the chancellor in his most personal moments. The private realm of experiences, however, does not contradict public knowledge. It is not an isolated realm, but rather part of the shared space of society. Death individualises, but the sermon presents this individuality as exemplary - as private but public.

\section{Bibliography}

Barløse Oluf Rasmussen, Sørgelig Klage offver Den Erlige/ Velb. oc Strenge Ridder H. Christen Friis til Kragerup/ oc Kong: May: Canseler/ Danmarckis Rigis Raad/ Nu salig i Herren/tile $n$ Christelig Amindelse/ oc hans effterlatte højbedrøffvede elskelige Frue/Fru Barbara Wittrop/Sampt deris elskelige/Velbyrd: oc Adelige Børn/til nogen Trøst/ offver deris Velb: S. Herris oc Faders hoederlig oc saglig Affgang (Copenhagen, Salomon Sartor: 1639).

Baschet J., Le sein du père: Abraham et la paternité dans l'occident médiéval (Paris: 2000). Brochmand Jesper Rasmussen, Hielp aff Himmelen, det er: Den CXXI. Davids Psalme/ andragen/der Christian Frijs til Kragerup/Kongel. May. Canceller/Danmarcks Rigis Raad/Befalnings=Mand offver S. Knuds Kloster udi Fyen/ oc Munckeliff=Kloster udi Norge/ hans Lijgs Begcengelse/ med Adelige Ceremonier bleff udi vor Frue Kircke i Kiøbenhaffn huldet/ udi hans Kongl. Maj. Egen Ncrværelse/ oc Danmarckis Riges Raads/ oc fornemme Adels offver=vcerelse/ saa oc Geistliges oc Verdsliges Folckrige Forsamling (Copenhagen, Melchiore Marzan: 1640).

Cicero Marcus Tullius, De Inventione (Cambridge, MA: 1949).

Hamm B., Religiosität im späten Mittelalter. Spannungspole, Neuaufbrüche, Normierungen (Tübingen: 2011).

Lund T.-T., Dagligt liv $i$ Norden $i$ det sekstende århundrede, 14. vols. (Copenhagen: 1879-1901).

Meier Johannes, In Funere Christiani Frisii, Domini de Kragerup, Equitis Aurati [...] lachrimce et planctus veri doloris (Copenhagen, Melchior Martzen: 1639). 
Melanchthon Philipp, Opera Omnia, vol. 2/2, eds. W.P. Weaver - S. Strohm - V. Wels (Berlin - Boston: 2017).

Moore C.N., Patterned Lives. The Lutheran Funeral Biography in Early Modern Germany (Wiesbaden: 2006).

Palladius Niels, Huorlunde ith Christet Menniske skal paa sin Soteseng beskicke sig til Døden (Copenhagen, n.p.: 1558).

Pernot L., La rhétorique de l'éloge dans le monde gréco-romain, 2 vols. (Paris: 1993).

Pernot L., Epideictic Rhetoric: Questioning the Stakes of Ancient Praise (Austin, TX: 2015).

Resch C., "Reforming Late Medieval Ars Moriendi: Changes and Compromises in Early Reformation Manuals for Use at the Deathbed", in Rasmussen T. - Øygaarden Flæten J. (eds.), Preparing for Death, Remembering the Dead (Göttingen: 2015) 153-172.

Resen Hans Hansen, Orationis Funebris De Magnifico, Perillustri \& incomparabili Heroe Dn Christiano Frisio (Copenhagen, Salomon Sartor: 1640).

Thomissøn Hans, Den danske Psalmebog met mange christelige psalmer (Lorenz Benedict, Copenhagen: 1559).

Wangsgaard Jürgensen M., "Spacing Death - Facing Death: Conceptualizing the Encounter with Death during the Early Modern Period", in Rasmussen T. Øygaarden Flæten J. (eds.), Preparing for Death, Remembering the Dead (Göttingen: 2015) 123-151.

Worm Ole, Monumenta Danica libri sex (Copenhagen, Joachim Moltke: 1643).

Worm Ole, Museum Wormianum seu Historia Rerum Rariorum (Leiden, Jean Elzevir: 1655). 